and then washed out with $1,080 \mathrm{ml}$. of fluid only.

The Table summarizes the amounts recovered in patients with barbiturate overdosage.

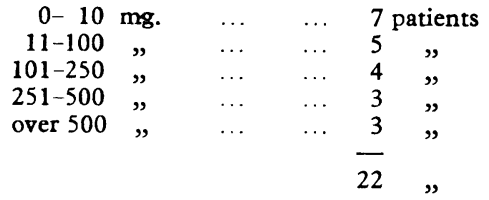

It will be seen that in no case did we fail to obtain some evidence of the drug, whereas Harstad et al. failed to do so in over half their cases. This may be because they used large volumes of fluid.

Dr. J. J. Alpert (19 December, p. 1593) advocates emesis. This can, of course, only be of value with a fully conscious patient, and in our experience few who have ingested significant amounts arrive in hospital early enough for this to be practical. It may have its place as a home remedy, but does not seem to us to have a place in hospital practice. We feel that at the moment the position regarding lavage should be summarized as followslavage with a small volume of fluid may be useful if strict precautions are taken to protect the lungs and the time since ingestion is short. -We are, etc.,

$$
\begin{array}{ll}
\text { St. James' Hospital, } & \text { David Caro. } \\
\text { London } S . W .12 & \text { E. KaweraU. }
\end{array}
$$

RBPERENCES

istarkenstein. B., Rost, E., and Pohl, J., Toxikologie, 1929, P 24. Berlin.
Marriott. H. L., Lancet, 1933, 1, 962.

s Harstad, E., Mëller, K.' O., an.' Simesen, M. H. Acto med scand, 1942, 112, 478.

\section{Nephritis and Skin Diseases}

SIR,--An association between nephritis and some common skin diseases is recorded by Dr. R. Summerly and Dr. P. W. M. Copeman (28 November, p. 1369). I here give brief details of a similar case.

The patient, a female of 61 , consulted me with general malaise, dysphagia, fever of $102^{\circ} \mathrm{F}$. $\left(38.9^{\circ} \mathrm{C}.\right)$, and a generalized blotchy erythematous rash, urticarial in places. She blamed the illness on a horse-fly bite several days previously, as she had always before reacted severely to insect bites, though never in such a manner as this. Other factors considered as a possible cause were two Anadin tablets taken a week previously and Thermogen plaster applied to a strained back at the same time.

After two days of treatment with antihistamines her condition had deteriorated generally. Urinalysis disclosed considerable albuminuria. She was admitted to Freedom Fields Hospital, Plymouth, under the care of Dr. H. A. W Forbes, for further investigation. Blood urea was found to be $260 \mathrm{mg} . / 100 \mathrm{ml}$., with a severe acidosis. E.S.R. $65 \mathrm{~mm}$. /hr. Mid-stream urine, numerous pus cells, scanty red blood cells, and Streptococcus faecalis grown on culture. $\mathrm{Hb} 68 \%$, blood-pressure $140 / 60 \mathrm{~mm}$. Hg. Investigations for L.E. cells negative. Chest $x$-ray-heart enlarged; lung fields normal. Over the course of several months her condition slowly improved and at the last count her blood urea was 105 mg. $/ 100 \mathrm{ml}$.

This patient had a history of scarlet fever in childhood and two general practitioners had recorded on her card in the past a high pulse pressure and aortic diastolic murmur. These signs were not elicited during the present illness, or on suhsequent investigations, but do suggest the nossibiliyy of rheumatic heart disease and the streptococcal hvpersensitivity discussed by Summerly and Copeman. It is also possible to implicate the horse-fly bite as an antigenic stimulus, or, indeed, one of the components of Anadin tablets (aspirin, phenacetin, caffeine, and quinine)

\section{-I am, etc.,}

East Looe, Cornwall.

J. C. Gates.

\section{Unusual Object}

SIR,-I can recall that a house-physician had an experience similar to that described by Dr. P. N. Stanbury (26 December, p. 1660). After a residents' party, when he had consumed a quantity of alcohol, the house-physician went to the ward and drank straight down about a pint of milk. Next morning he was feeling extremely ill, and after vomiting several times brought up an object larger but similar to that described, undoubtedly solidified milk. It was thought by its shape that this object had been obstructing the pylorus, and the instant relief of all symptoms on disimpaction confirmed this view.-I am, etc.,

\section{Royal West Sussex Hospital \\ Chichester, Sussex.}

J. D. Whiteside.

Sir,-Dr. P. N. Stanbury (26 December, p. 1660) may be interested to know that I too have had a case of a child who vomited a solid mass of caseinated milk, which appeared to have been causing an ohstruction in the pylorus. In my case the child had an acute tonsillitis with a pyrexia and persistent vomiting for three days. The vomiting ceased dramatically immediately after the mass of solidified milk had been vomited.-I am, etc.,

Great Yarmouth

G. HURST

Norfolk.

\section{New Dermatosis}

Sir,-I am prompted by your leading article (19 December, p. 1547) entitled “A New Dermatosis" to report that we have recently seen a patient with a clinical syndrome apparently identical with that described by Sweet. ${ }^{1}$

A 66-year-old female gave a past history of erythema nodosum in 1937 and severe osteoarthritis of hips and knees. She presented in May 1964 with a two-week history of malaise and aching in her limbs, neck, and back. A rash had appeared on her hands on the day of admission to hospital. It consisted of raised discrete patches of erythema on the dorsum of the hands and forearms, a plaque on the back of the neck and one on the right knee. General examination revealed a few small discrete cervical lymph nodes, marked hypertension, and firm liver edge iust palpable below the cosral margin. She ran a remittent fever up to 102 to $103^{\circ}$ F. $\left(38.9-39.5^{\circ} \mathrm{C}\right.$.). Within the next few days the skin lesions, which were painful and irritating, became confluent and some areas began to develop small vesicles. Her E.S.R. was $62 \mathrm{~mm}$ at one hour; total white cell count $14,300 / \mathrm{c}$ mm. of which $82 \%$ were neurrophils. There was 0.3 part per 1,000 of albumin in the urine with occasional pus cells. Electrophoresis of the plasma proteins showed a moderate increase in $\alpha_{1}$ and $\alpha_{2}$ glohulins. Blood cultures were sterile. Tests for L.E. cells and antinuclear factor were negative. Biopsy of the skin lesion showed a normal enidermis but marked dermal inflammatory reaction consisting of histiocytes and polymorphs. Culture of material from the biopsy was sterile.

Possible diagnoses considered included erysipe loid of Rosenbach (although there was no his- tory suggestive of contact with infected material), septicaemia, or a "collagenosis." A course of tetracycline followed by penicillin and streptomycin were without effect on the rash or pyrexia. At this point Dr. P. J. Hare suggested the condition described by Dr. Sweet. Treatment was started with prednisolone, $10 \mathrm{mg}$. three times a day. The pyrexia fell to normal within 24 hours and the skin lesions faded over the next week with desquamation. After two weeks the blood leucocytosis had subsided. During the succeeding months she was gradually weaned off steroids and they were stopped in October without recurrence of symptoms.

This would seem to be a further example of acute febrile neutrophilic dermatosis.-I am, etc.,

$$
\begin{aligned}
& \text { Medical Unit, } \\
& \text { University Collegè Hospital, }
\end{aligned}
$$

1 Sweet, R. D., Brit. F. Derm., 1964, 76, 349.

\section{Buccal Oxytocin}

SIR,-Since my return from Sweden my attention has been drawn to the correspondence in your columns on buccal oxytocin and in particular to the letter by Professor J. H. M. Pinkerton (28 November, p. 1393). A woman does not go into labour because of uterine contractions (which occur during all her reproductive life) unless they are preceded by changes in her vagina and cervix, in the composition of her blood, and probably by altered response to stimuli in her hypothalamus. These changes are associated with an increased sensitivity of her myometrium to oxytocin. It is nearly 30 years since I postulated that the hypothalamus controlled menstruation, ovulation, pregnancy, and parturition; that the onset of labour resulted from the removal of an "inhibition," not from an increase of oxytocin in the blood; and that the effective concentration of oxytocin in the blood matched the effective concentration of antidiuretic hormone (A.D.H.). The very first drip used for inducing labour was calculated on this assumption, and the amount then used $(5 \mathrm{mU} / \mathrm{min}$.) is the amount I advocate to-day. ${ }^{1}$ Dr. Caldeyro-Barcia ${ }^{2}$ agrees that the maximum amount of oxytocin given should not exceed $8 \mathrm{mU} / \mathrm{min}$, and $\mathrm{Dr}$. Hendricks ${ }^{3}$ affirms that $80 \%$ of his induction cases did not need more than $5 \mathrm{mU} / \mathrm{min}$. of Syntocinon. The truly physiological oxytocin drip can be given to any patient deemed worthy of a trial of labour, whatever her past obstetric history. Most of those who use the oxytocin drip for inducing labour use higher concentrations of oxytocin, but it has never been shown that the pharmacological drip is more effective than the physiological one, and it is certainly less safe. Nevertheless oxytocin given into a vein can be stopped immediately, and I know of no centre in this country using this method efficiently where rupture of the uterus has occurred.

It is thus surprising that Professor Pinkerton writes: "Just how safe ... [the buccal routel ... is compared with the intravenous method is not yet established " notwithstanding the fact that he knows of six cases of rupture of the uterus occurring in a relatively small series of cases in which this route has been used. One wonders how many foetal or maternal deaths must occur before this point is settled.

The supposed advantages of the buccal route are: (1) that it is easy to use ; and (2) 
that women do not like the intravenous drip. It is certainly easy to use and can be ordered over the telephone. Whether women would prefer the limitations imposed by the lozenges for from 24 to 48 hours to a $1: 5$ chance of a drip is not known, but they would all opt for the method which is safest for their unborn child. In my view the buccal route is retrograde for four reasons: (1) it involves the use of heroic amounts of oxytocin; (2) its rate of absorption from the buccal mucous membrane is unknown and varies from patient to patient and probably from hour to hour in any given patient; (3) unless the woman is " ready" to go into labour the sensitivity of her myometrium must increase to oxytocin and often at the very time that the amount of oxytocin being absorbed is also increasing, and nobody can believe that this dangerous " crossing" of the levels can be speedily countered by removing the lozenge ; and (4) it differs little from the old and discarded nasal route and is therefore historically retrograde.

The buccal route cannot be justified on theoretical grounds, and its record in this country is already calamitous and may prove so disastrous as once more to stir up opposition to the use of oxytocin until the birth of the child is imminent.-I am, etc.,

\section{University College Hospital,}

$$
\text { G. W. Theobald. }
$$

\section{RIPERENCES}

1 Theobald, G. W., in British Obstetric Practice, ed. A. Claye, p. 1055, 3rd ed., 1963. Heinemann, London.

2 Caldeyro-Barcia, R., 1964, personal communication.

3 Hendricks, C. H., 1964, personal communication.

\section{Hospitals for Subnormal Patients}

SIR,-For various reasons it has been stated that $400-500$ beds is to be the optimum for a hospital for subnormal and severely subnormal patients. The validity of some of these reasons can be questioned, and it is doubtful whether hospitals of this size can properly fulfil their appropriate functions, which are to be a social training ground, a shelter, a school, a place of control, a community as well as being a hospital in the best sense of the word where these patients can receive expert medical and nursing care and where fundamental research and inquiry can be made into the aetiology, pathology, and prevention of mental deficiency.

As secondary functions, the hospital should serve as a training school for all grades of staff required in such hospitals, and as an orientation centre for students in the disciplines of medicine, psychology, nursing, education, and social science. There should also be links with the nearest university and teaching school in all the above disciplines, and also with local authorities by the provision of out-patients clinics, both intra- and extramural, and on all matters connected with the retarded, such as aid in ascertainment, investigation, diagnosis, prognosis, and disposal.

The hospital should also serve as an investigation centre so that medical men, local authorities, magistrates, children's officers, and parents themselves can be advised on matters concerning the retarded. It should also be the centre of its area for the temporary relief of any acute or chronic disorder in the retarded.
A review of the Hospital Year Book 1965 shows as follows -208 hospitals or units housing the retarded can be identified. Of these 103 have less than 100 beds (average 44), another 30 have less than 200 (average 151), while the total with less than 500 beds is 172 or $82 \%$ of the whole. At the other end of the scale, only 18 hospitals are shown as having 750 beds or more. Such statements as "It has for too long been the custom to house mental defectives in over-large, gloomy, remote institutions, etc." in view of these figures would not appear to be wholly true.

Consideration should be given as to whether hospitals of the size now being planned by the Ministry can in fact carry out their proper functions, whether they will attract staff of the right calibre, and whether if they are given the necessary facilities to carry out all their functions they will indeed be financially realistic. There is no proof that the majority of smaller hospitals have in the past contributed more to the study of mental subnormality than have the larger hospitals, and there is no proof that the smaller the hospital the more efficient does it become.

It seems more than doubtful whether new hospitals of 400 beds will ever become viable enough to fulfil their basic functions. The viability of these hospitals will also be in doubt whenever they come within the administrative control of a general or mixed group of hospitals as appears to be the growing pattern. Hospitals for subnormal patients require an expertise and a specialized emotional approach among members of management committees if the same sound basic principles of medicine, psychology, nursing, education, and the social sciences as they apply to normal individuals are to apply, as of right, to the retarded.

Such expertise and approach are best found in management committees who specialize in this work.-I am, etc., GEORGE
The Prudhoe and Monkton Hospital,
Northumberland. Grorge McCoull.

\section{Implantation Dermoid of Neck}

SIR,-Implantation dermoids commonly occur in hand or sole, though they can be encountered elsewhere too. Here it is desired to put on record a case of implantation dermoid occurring in the neck after excision of submandibular salivary gland.

Mr. A. B., age 49 years, was seen with an unusual lump in left side of his neck. It had appeared 14 weeks after the excision of his left submandibular salivary gland for a calculus, under the scar. This lump was $5 \times 2.5 \mathrm{~cm}$. in size and moved with deglutition. It felt doughy and could be indented like putty, becoming prominent again after a few acts of swallowing. It was quite painless and there was no bruit over it, nor was there any history of dysphagia or regurgitation of food material suggestive of a pharyngeal pouch. The swelling did not alter in any way during a period of observation of six weeks and consequently it was explored.

After deepening the incision through platysma a very large cyst was encountered with a welldefined capsule. This cyst was filling the whole of the region formerly occupied by the submandibular gland and was extending backwards and upwards into the ront of the neck and forwards into the floor of the mouth. It had only one firm attachment which was anterinrly on the hyoglossus deep to the mylohyoid muscle-hence the mobility with deglutition. The cyst was enucleated without difficulty.

On opening, the cyst was found to contain faecal-looking brownish material of the consistency of sebum. On microscopy the section showed the cyst to be lined by epidermis and to contain a large amount of keratin. There were some foreign-body giant-cells outside the cyst, and mild chronic inflammatory cell infiluration outside the cyst wall. The appearances were those of an epidermoid cyst consistent with implantation.

I am thankful to Mr. J. G. Jamieson for allowing me to publish this case.

-I am, etc.,

Dryburn Hospital,
Durham.

S. K. Agrawal.

\section{Delays in Out-patients}

SIR,-Dr. G. W. Garland (2 January, p. 57) asks why so many consultants limit their clinics. It may be that after $3 \frac{1}{2}$ to 4 hours in a clinic most consultants feel that they can no longer give an opinion of value.I am, etc.,

Bournemouth, Hants.

SIR,-I would like to support Dr. G. W. Garland's view (2 January, p. 57) that consultants have some responsibility in this matter.

For the past year I have made it a routine at each out-patient clinic to note on my appointments list the date of each general practitioner's letter and the number of days elapsing before the patient was seen. Whenever the delay reached 14 days, the appointments office was instructed to increase the number of new patients seen at each clinic by one or, if necessary, two. I have found that this modest increase was required only for a few weeks from time to time during the year and it has almost completely eliminated delays of more than 14 days.

If it were generally adopted, this simple measure would greatly ameliorate a problem which is becoming a serious reproach to the National Health Service.-I am, etc.,

Whittington Hospital, A. L. JACOBS.

London N.19.

\section{Education in First Aid}

SIR,-In reply to Mr. N. Capener (19 December, p. 1596) health education in schools has always been encouraged by the central department-i.e., Board, Ministry, and now Department of Education and Science, and a H.M.I. is responsible for the subject. There is also a publication, Health Education, ${ }^{1}$ which in its successive editions has kept pace with medical and educational thought. The last edition includes a chapter on accident prevention, and it states that simple facts about first aid should be within the grasp of every boy and girl of secondary school age. A warning is added, however, that inadequate first aid does more harm than good, and the question is asked, "Does the staff include anyone with real knowledge and experience of the subject ?" Similarly a current textbook for student teachers remarks (p. 237, " First aid . . . can be a most helpful introduction to 